\title{
NESTING BEHAVIOR OF THE SWALLOW-TAILED HUMMINGBIRD, Eupetomena macroura (TROCHILIDAE, AVES)
}

\author{
ONIKI, Y. and WILLIS, E. O. \\ Departamento de Zoologia, Unesp, CEP 13506-900, Rio Claro, SP, Brazil \\ Correspondence to: Yoshika Oniki, Departamento de Zoologia, Unesp, CEP 13506-900, Rio Claro, SP, Brazil, \\ e-mail: ewillis@rc.unesp.br \\ Received May 3, 1999 - Accepted March 16, 2000 - Distributed November 30, 2000
}

(With 5 figures)

\begin{abstract}
An August or winter nestling of Eupetomena macroura was fed only every 40-50 min for at least 24 days in the nest, with fewer feedings at midday. As in other hummingbirds, it was brooded only the first week or two, and left alone even on cool nights after 12 days, probably due to the small nest size. The female attacked birds of many non-nectarivore species near the nest, in part probably to avoid predation. Botfly parasitism was extremely high, as in some other forest-edge birds.
\end{abstract}

Key words: nesting, hummingbird, Eupetomena macroura, parasitism, predation.

\section{RESUMO}

\section{Comportamento reprodutivo do beija-flor-tesoura, Eupetomena macroura (Trochilidae, Aves)}

Um jovem, de agosto ou inverno, de Eupetomena macroura foi alimentado somente a cada 40-50 min., com menos alimentações no meio do dia. Ficou, pelo menos, 24 dias no ninho. Como em outros beijaflores, a fêmea permaneceu no ninho à noite somente na primeira ou segunda semana e deixou o jovem sozinho mesmo em noites mais frias após 12 dias, provavelmente devido ao tamanho pequeno do ninho. A fêmea atacou aves de muitas espécies não-nectarívoras nas proximidades do ninho, em parte provavelmente para evitar a predação. O parasitismo por larvas de dípteros foi extremamente alto, como em algumas outras espécies de aves de borda.

Palavras-chave: nidificação, beija-flor, Eupetomena macroura, parasitismo, predação.

\section{INTRODUCTION}

The Swallow-tailed Hummingbird (Eupetomena macroura, Trochilidae) is the best known hummingbird to Brazilians, because it is rather large $(9.01 \pm 0.90 \mathrm{~g}, \mathrm{n}=478)$, has a conspicuously forked tail and is commonly found in back yards and gardens where flowering plants are available. In 1993, students helped us watch a nest from which a first brood had departed in July (G. A. Bencke, pers. comm.), to determine patterns of activity.

\section{MATERIAL, STUDY SITE AND METHODS}

The nest, on lawns of the Universidade Estadual Paulista campus (2223'S, 47³3'W, 620 m elevation) in Rio Claro, São Paulo State, Brazil was studied with binoculars Nikon $9 \times 23$ and Zeiss $8 \times 30$, for 203.3 hours.

One to three persons watched quietly, 10 or so meters away, to avoid disturbing the female. 


\section{RESULTS}

\section{Nest and breeding period}

The cup nest was $2.3 \mathrm{~m}$ in a $6 \mathrm{~m}$ small tree, on a branch $1 \mathrm{~m}$ from the $13 \mathrm{~cm}$ diameter trunk. It was $44 \mathrm{~mm}$ external diameter, 32 internal, 48 external height and 18 internal. One young was present, 13 August to 6 September when it left; we watched it in a few nearby trees that day and the next.

Willis found four other nests 1.5-2.5 m up in Rio Claro, with young Sept. (2 nests) and Oct. (2). A. Z. Antunes (pers. comm.) found a nest with two eggs 19 August in a Cochlospermum sp. (Cochlospermaceae). Young disappeared between 25 and 28 Sept. The Forest Police brought one large young on 2 June 1997; apparently it had fallen from a nest. In Campinas, nestlings were fed $5 \mathrm{~m}$ up in Aug. In Santa Teresa, Espírito Santo, Willis found nests 2 and $3 \mathrm{~m}$ up in Feb. and Sept., the latter with young. He noted large young fed out of the nest in April at Santa Teresa and 3 Jan. at Araçatuba (SP), and adults carrying plant down at Itirapina (SP) in Sept., Águas de Santa Bárbara (SP) in Aug., and Barrolândia (BA) in July.

Reiser (in Snethlage, 1928) reported a young out of the nest in March. Two eggs were reported in June; nestlings in another nest, July; young out in Aug.; carrying material in December (Erickson \& Mumford, 1976). Ruschi (1986) reports nests, giving " 22 " days as the nestling period, but does not present data. Nests reported by Grantsau (1988) were cup-shaped structures on forks or branches, of soft plant down, the external wall with mosses and lichens tightly woven with cob webs. Measurements were external height $40 \mathrm{~mm}$, depth 20 $\mathrm{mm}$, external diameter $54 \mathrm{~mm}$ and internal diameter $34 \mathrm{~mm}$. He found nests or incubating birds in February, March and June.

\section{Brooding}

Until 19 August, the young was brooded several minutes on every visit, for about half $(36 \%$ $58 \%$ ) of the day (Fig. 1). On 19 August, brooding periods were shorter than usual (4-13 min, $\mathrm{X}=$ $8.9, \mathrm{n}=10$; once 26 min with a brief flight off, during wind and rain). On preceding days, brooding was 2-60 min, with peaks of 25 records of 7-11 min and 24 from 17-21 $\min (\mathrm{X}=14.5 \mathrm{~min}, \mathrm{n}=$ 77). On 20 August at 17:02 and 17:54 the first two visits without brooding were noted; and brooding was only $9.9 \%$ of the afternoon. The next two days, brooding was regular after morning visits but infrequent after 15:00 (about 18\% each day). Most brooding was 3-11 $\min$ on these two days $(n=30$, plus visits of 13, 14, 19, 25 and $25 \mathrm{~min} ; \mathrm{X}=7.9$ ). On 25 August (only checked midday 24 August, with one $11 \mathrm{~min}$ brooding in $170 \mathrm{~min}$ ) the female no longer went on the nest in the evening, and she brooded only $1 \%$ of the afternoon. She did not brood at night after 25 August. However, she was brooding 5:54 to 6:06 the morning of 3 Sept., and perhaps brooded the nestling at dawn other days (not checked).

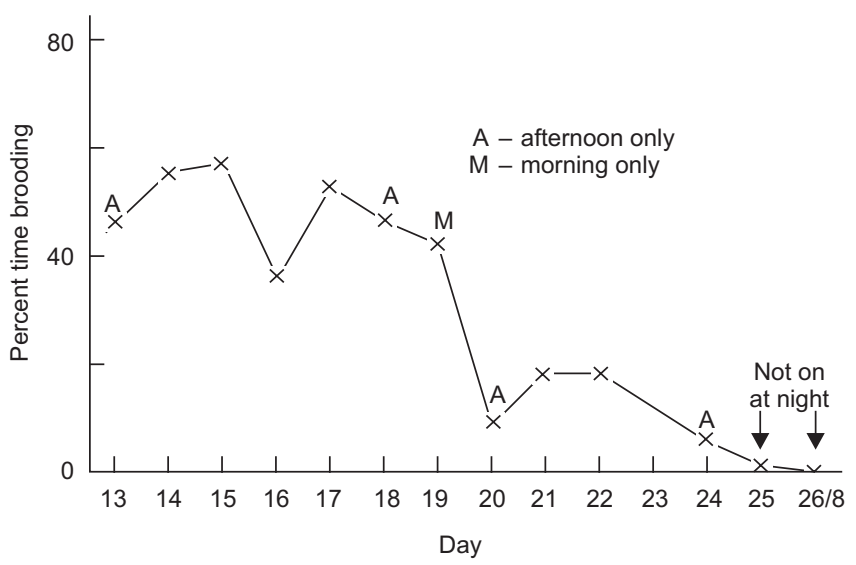

Fig. 1 - Percent of time brooding nestling. 
Earlier she went on for the night 17:51-18:08, except 18:15 and 18:13 on 21-22 August when sunset was later. On these two days, unlike 6 earlier ones when we saw her go on, she did not feed the young on her last visit of the day; but she had fed 1-5 min earlier in both cases.

On the nest (Fig. 5a), she at times pecked the outside of the nest (for insects?), wiped her bill on its edge, or scratched her head over the wing. She could preen breast and wings; once she opened her tail as the wind blew. She could stick her tongue out briefly a few times $(3 \mathrm{x})$, or yawn. To leave, she looked about before spreading her wings, hovering forward or (a few times) backward. She could stop briefly in nearby trees on approach or departure.

\section{Feedings}

Feedings were about every 40-50 min, on average (Fig. 2), but intervals varied greatly. The figure indicates average time away from nest (lower line), average time between arrivals at nest (middle line), and average time between feedings (upper line). On 31 Aug., $186 \mathrm{~min}$ elapsed between feedings at $12: 33$ and $15: 39$ but only 4 min at 15:55-15:59 on 22 August. With short intervals, the second visit was usually to brood rather than to feed. Fig. 3 shows that feedings (per hour watched at a given hour on several days, for instance between 6 and 7 am) were slightly over 2 per hour at 6-8 am and near 2 per hour at dusk, dropping to near 1 per hour 13:00-16:00 during the warmest hours of the day.

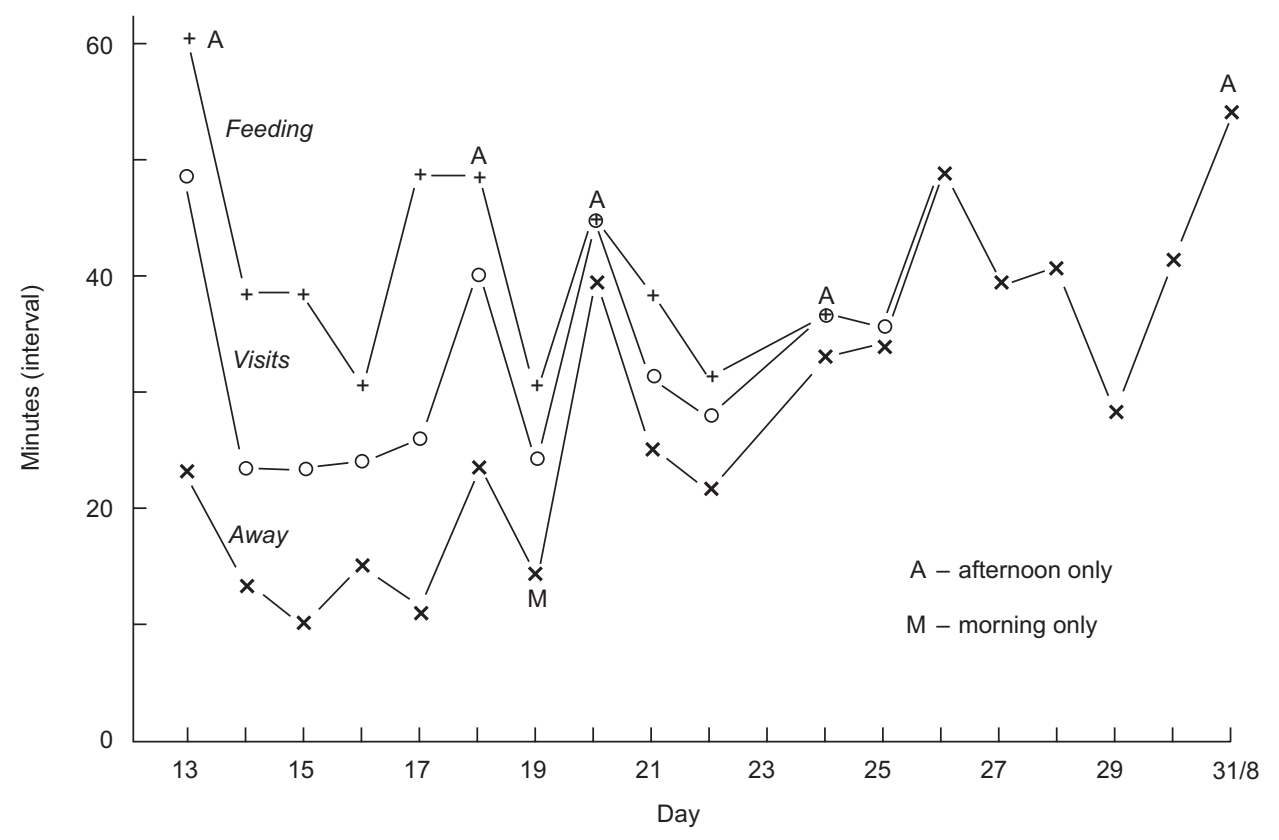

Fig. 2 - Intervals between feedings and visits.

After the female stopped brooding at night, she fed less often after 6 pm (4 vs. 7 visits in 8/ 8 days after/before 23-24 Aug.). On 30 Aug., her last feeding was $17: 15$; she fed other days to $17: 56$ or so. She did feed more after 4 pm (3-6 visits, $X=4.4) 25$ Aug. on ( $X=3.4$, or 2-5 visits, earlier), despite the drop from $6 \mathrm{pm}$ on.

At times, the female waited 3-27 sec on the nest rim before starting to feed, but she usually fed quickly. She fed by regurgitating several times on each visit (Fig. 5b), into the open beak of the young bird. It usually turned its beak backward to feed. She often looked to the left between regurgitations; once she wiped her beak on the nest edge. Three regurgitations per visit $(n=80$ of 212) were most frequent, with two as frequent the last full day in the nest $(\mathrm{n}=7$ each) and more frequent after departure $(n=12$ of 23 cases versus 7 ca- 
ses of 3). Of 19 cases of 6-8 regurgitations, only one (of 7) was recorded after 28 August. Half the 26 cases of 5 regurgitations were after that date, so the young may have been more able to swallow after the $28^{\text {th }}$. Feedings took 9-80 seconds. Once, after the young left, she hovered while regurgitating twice into its beak. In several cases, she foraged for insects in nearby small trees before feeding young. Once she fed briefly, sat, then fed once while sitting (8:01 on 15 Aug.). The young refused two early feedings on 5 Sept. and one at 11:40 on 29 Aug., indicating that the female could easily have fed another nestling, at least after Oniki removed fly larvae (see below). The female often sat and preened in a nearby tree after she stopped brooding, indicating she was not working hard. She scratched her head over the wing, but once scratched her neck under the wing.

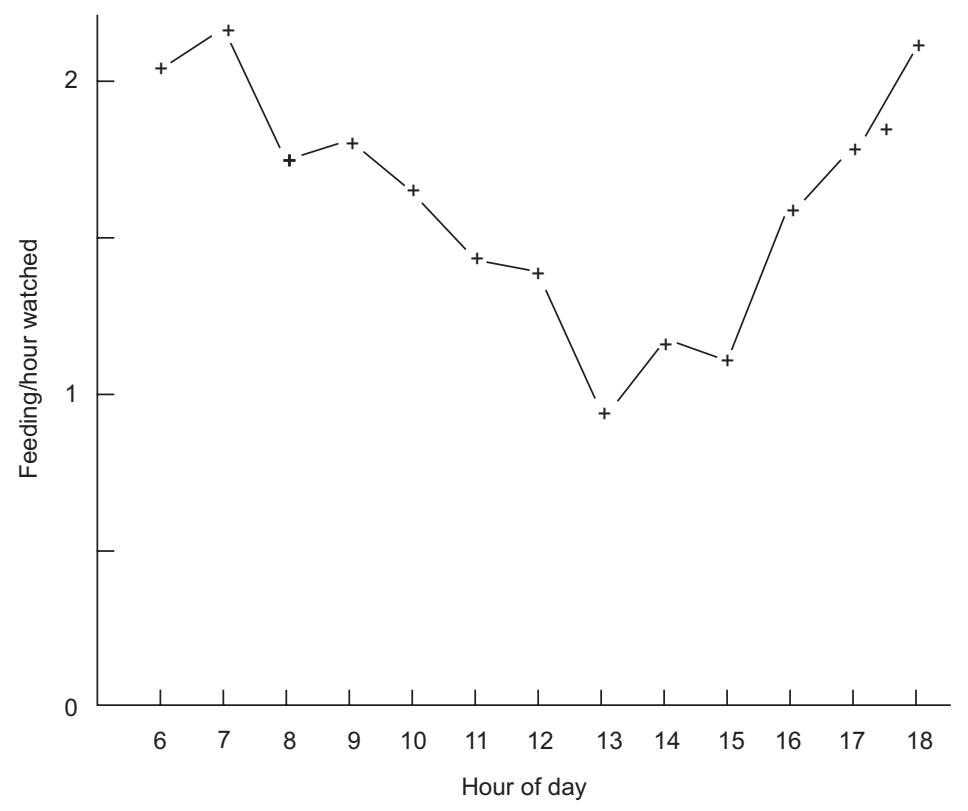

Fig. 3 - Number of feedings per hour watched at different times of day.

\section{Young}

Growth of bill, tarsus and wing (Fig. 4) and in weight (Table 1) were regular, since we removed parasite fly larvae. The sharp claws held on to the nest lining 18 Aug. on. Commonly, the young defecated when removed. The eyes were open 22 Aug., when handled; it was raising the tail to defecate outside the nest. 29 Aug. the pinfeathers were $1 \mathrm{~mm}$; 24 Aug. ones on the back were opening but seemed dull in color. The head was blue and back green by 29 Aug. 26 Aug. on, the upper mandible was getting dark. A buff spot was visible behind the eye by 4 Sept. Occasional movements were visible 22 Aug., though only the bill and top of head were visible (Figs. 5c, d); in one case, the female left the nest because the young was moving after feeding; she returned a few seconds later to sit. Once it moved because of a fly. Preening, mostly in heat 11-16 h, was noted 26 Aug. on. Occasionally it yawned or stuck the tongue out, mostly when hot (Fig. 5c); later, it kept the beak open for long periods, closing it briefly now and then (Fig. 5d). It could champ the beak or turn in the nest. The bill could be raised or not (Figs. 5e, f).

Stretching both wings was first noted 29 Aug., but was infrequent until 4 Sept., the day after a couple of cases of beating wings high in the nest (Figs. 5g, h). Once, on 2 Sept., it beat its wings perched on the nest edge (Fig. 5j) but soon returned to the nest. 


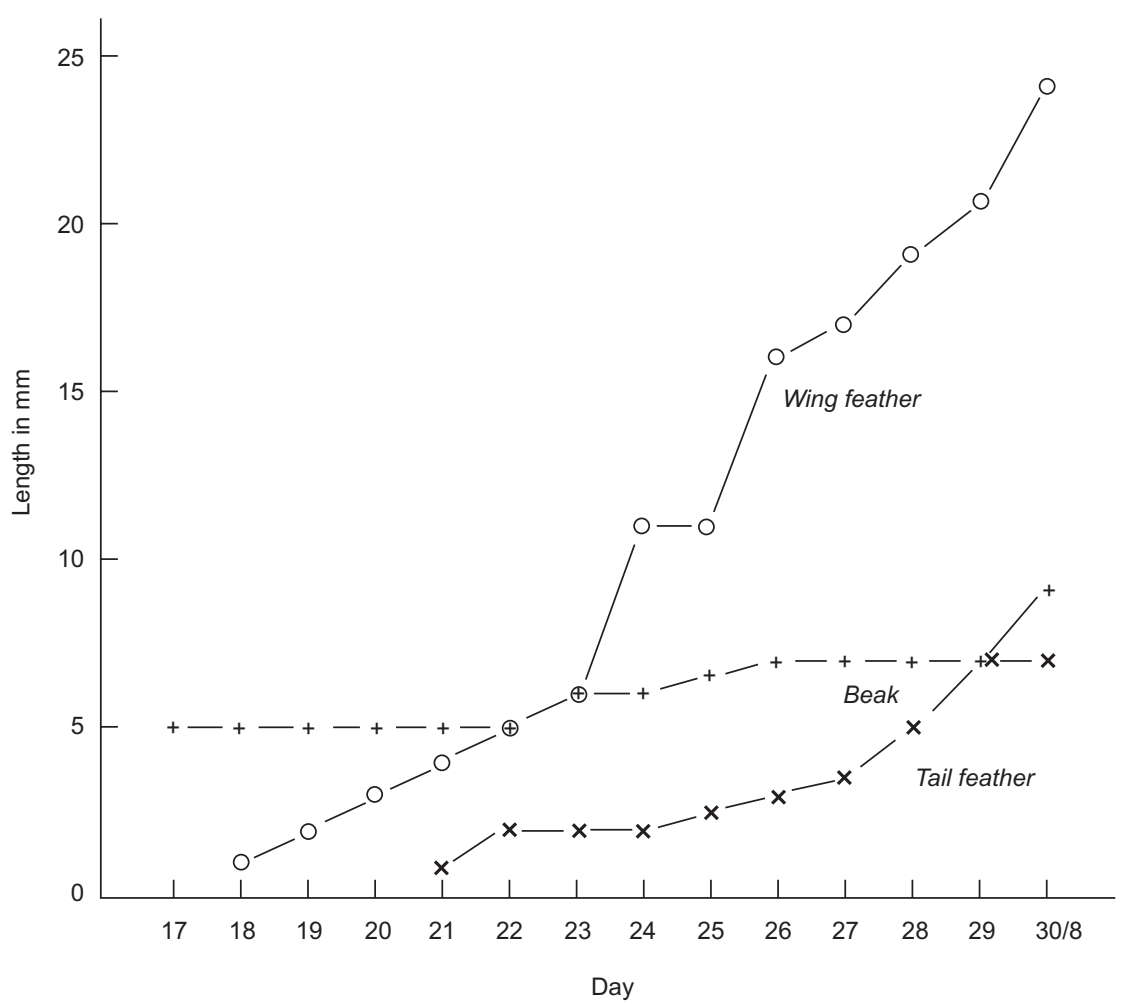

Fig. 4 - Growth of beak, wing, and tail in $\mathrm{mm}$.

TABLE 1

Diptera fly larvae collected from the nestling Eupetomena macroura, and its weight.

\begin{tabular}{|c|c|c|c|c|}
\hline Date & Time & N. larvae & $\begin{array}{c}\text { Weight (gms) young with } \\
\text { larvae }\end{array}$ & $\begin{array}{c}\text { Weight (gms) young } \\
\text { without larvae }\end{array}$ \\
\hline 15.08 .93 & $11: 15$ & 8 & - & 4 \\
\hline 16.08 & $11: 22$ & 9 & 4.3 & 5.7 \\
\hline 18.09 & $13: 35$ & 2 & 5.7 & 5.4 \\
\hline 19.08 & $11: 18$ & 7 & 6.1 & - \\
\hline 21.08 & $14: 06$ & 1 & 6.7 & 7.5 \\
\hline 22.08 & $12: 10$ & 5 & 8.0 & 8.1 \\
\hline 24.08 & $14: 00$ & 8 & 8.8 & 8.3 \\
\hline 25.08 & $13: 48$ & 3 & 8.8 & 9.0 \\
\hline 26.08 & $13: 55$ & 5 & 9.8 & 8.8 \\
\hline 27.08 & $15: 16$ & 4 & 9.8 & 9.0 \\
\hline 28.08 & $12: 27$ & 5 & 11.0 & 8.5 \\
\hline 29.08 & $13: 19$ & 1 & 8.8 & 9.8 \\
\hline 30.08 & $11: 32$ & - & - & \\
\hline
\end{tabular}




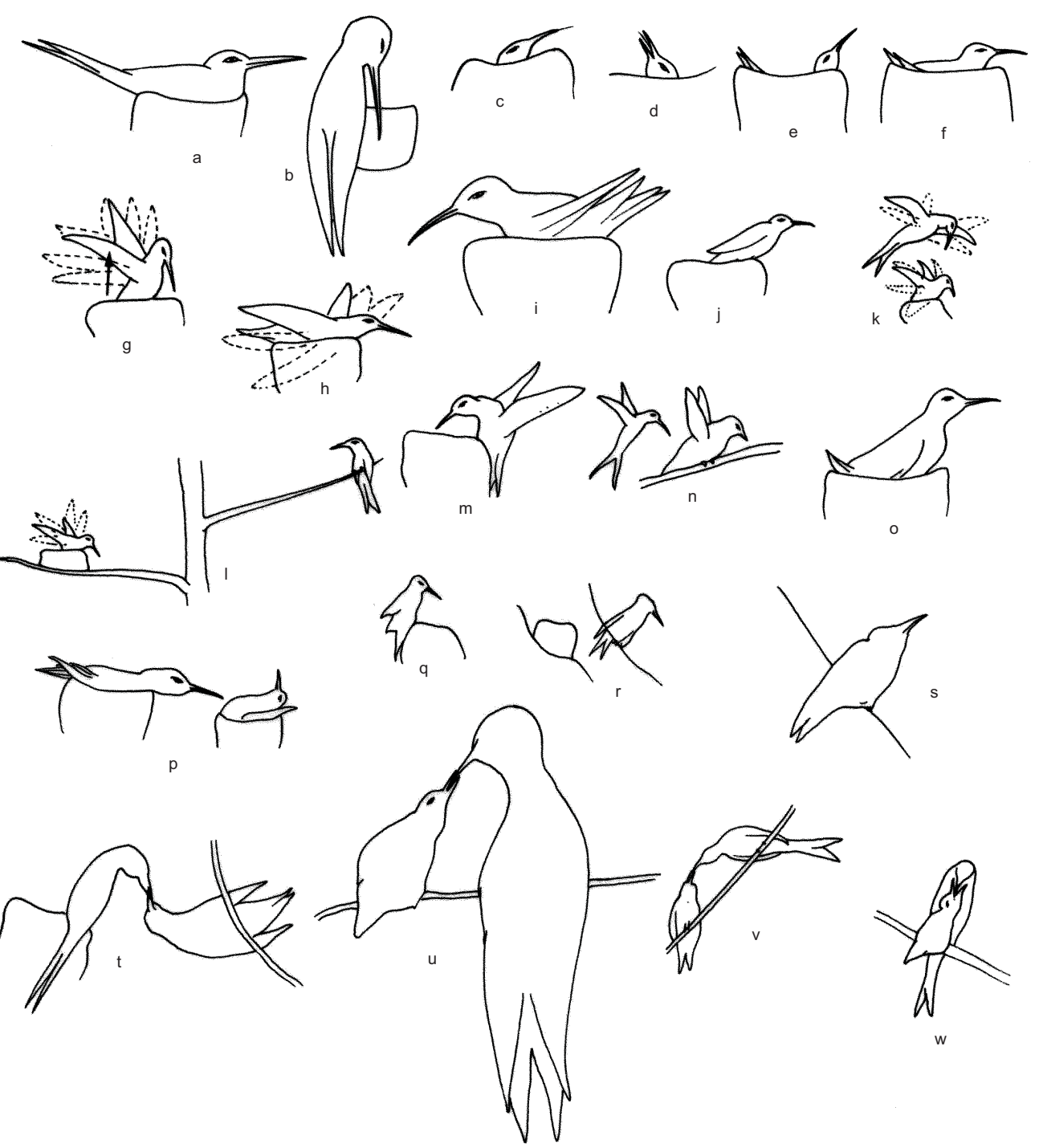

Fig. 5 - a - Adult sitting on nest rim after a feeding; $\mathbf{b}-$ Adult perched on nest rim and feeding nestling; $\mathbf{c}-$ Nestling, tongue in and out; $\mathbf{d}-$ Nestling begging for food; $\mathbf{e}, \mathbf{f}-$ Nestling sleeping: wings folded and bill slightly up or not; $\mathbf{g}$ - Young exercising wings, standing on nest; $\mathbf{h}$ - Young exercising wings, sitting on nest; $\mathbf{i}$ - Young sitting high on nest; $\mathbf{j}$ - Young perches on nest rim but soon returns to nest; $\mathbf{k}-$ Young exercising wings while female hovers over; both vocalizing; soon female perches on a branch nearby $(\mathbf{m}) ; \mathbf{m}$ - After beating wings, young lost balance and almost fell from the nest; $\mathbf{n}-$ Female attacks Columbina talpacoti perched on nest tree, the ground dove raising both wings but had to fly, chased by the very persistent female; $\mathbf{o}$ - Young watches from the nest, high on nest rim; sits horizontally and stretches neck or looks upward (p); q - Young exercising wings but perched "outside" the nest; or trained wings again and went to a branch above the nest $(\mathbf{r})$; and remained on branch (s); $\mathbf{t}-$ Female arrived and young out, so that it was fed ( $3 \mathrm{x})$ on the branch, almost upside down; $\mathbf{u}, \mathbf{v}, \mathbf{w}-$ Female feeds young on perch.

Wing-beating sessions were also frequent 45 Sept., occasionally just after a feeding (Figs. 5k, 1). At $16: 54$ on the 4 th, the young was beating wings on the nest edge (Fig. 5g). Four times the next day the young practiced on the nest rim (almost falling from the outside of the nest once,
Fig. 5m), once on a nearby branch, but returned inside the nest. Once it slid up on the nest edge, returning. It gave brief call notes during some sessions on the $5^{\text {th }}$; at $08: 43$, it exercised wings while the female hovered over, both vocalizing; soon the female perched on a nearby perch (Figs. 
$5 \mathrm{k}, 1)$. On the $4^{\text {th }}$ and $5^{\text {th }}$, it watched nearby wasps (Figs. 5o, p) or pecked at lichens on the outside of the nest, the latter also recorded 2 Sept.

On 6 Sept., it fluttered wings at 7:00 and 7:01, almost falling out the second time. At 7:03, it flew to a nearby twig (Figs. 5q, r, s). The female returned to the empty nest 7:11, pecked inside, then hovered chipping nervously; when the young called, she flew to it and fed it, almost knocking it pendent on the perch (Fig. 5t). Later feedings were less agitated, the young often turning along the twig to be fed (Figs. 5, u, v, w). 8:11 it fluttered, then 8:13 flew to another twig, and 8:26 to a third one.

It was still preening and scratching neck or head over the wing frequently, or stretching the wings; and it practised fluttering without leaving the perch repeatedly in the morning. After noon, short flights replaced most of the fluttering or preening sessions; but it was a windy day, which may have reduced overheating. It pecked nearby leaves twice near mid-day, perhaps after small insects. The young was left alone after a feeding at 17:58. It was not on that branch at 7:00 on 7 Sept., and 7:25 on it was being fed $7 \mathrm{~m}$ up in a nearby tree. By 11:20 it was $10.5 \mathrm{~m}$ in another tree, still fed occasionally ( 3 times by 8 am, 3 more by 11:20).

The young brought by Forest Police fed well on sugar water, spiders and flies captured around the house. Although well feathered and with tail half the adult size, it did not preen actively, became flat chested, and did not survive.

\section{Interactions with other birds}

The female sometimes fled the nest when students passed or raised her head when a student or bicyclist passed. Other birds in or below the nest tree or nearby trees could be attacked (12 records Mimus saturninus, 7 Columbina talpacoti, 6 Machetornis rixosus; 5 each Crotophaga ani, Zonotrichia capensis, Molothrus bonariensis; 4 Pitangus sulphuratus; 2 each Elaenia flavogaster, Cyanocorax cristatellus, Thraupis sayaca; once Gampsonyx swainsoni (when it flew), Colaptes campestris, Furnarius rufus, Satrapa icterophrys, Pyrocephalus rubinus, Tyrannus melancholicus). Twice she attacked a Polystes wasp near the nest. The female off the nest was alert or gave "tik" notes toward Buteo magnirostris, Guira guira (4 times), Pitangus (3), Tyrannus (1), and Cyanocorax (1), or to dogs and humans. Often the object of her "tik" notes was not evident, or several other birds were in trees near the nest tree.

Chases of other Eupetomena were frequent, some probably of a juvenile or two in the area: there were 47 cases plus 6 of 3-bird chases. One to 4 Eupetomena could "tik" in the area in the evening, especially when the nestling was older. Eleven cases of hovering over or in front of a sitting bird, possibly courtship, were also noted. It was not possible to verify activity, normally; the female may not even have been involved in several cases. Hovering courtship was 7-11 and 15-18:15 $\mathrm{h}$, chases mostly at the same hours (the latter especially common at dusk, after $18 \mathrm{~h}$ ).

Attacks on larger birds were never after 18 h, but were unusually common (18 cases) 17-18 h; they were fairly common $10-17 \mathrm{~h}$ too, less common early in the day. Several late-day cases were related to swarming termites, attracting many birds. Other cases involved $C$. talpacoti pairs starting to roost in the nest tree, which the female Eupetomena never allowed (Fig. 5n), perhaps because they could attract owls or other predators. Another reason for interactions with other species could be that the small nest tree and nearby trees were at the edge of a large grassy lawn and several breeding species were collecting sticks for nests (Columbina talpacoti, Columba picazuro) or food for nestlings (Machetornis rixosus, Mimus saturninus). M. saturninus and $C$. picazuro nests were in trees we could watch from our observation position, while activity of adults was watched as well.

\section{Parasites}

On 15 August at 08:28, the female was itchy and scratched the head over the wing with the right foot. This kind of preening, while sitting on the nest, was also observed on 17 Aug. (09:23, 10:44). At 11:49, the female made movements like she was feeding the young, turned about and pecked inside the nest several times as if catching something. As the nestling grew, it was difficult for her to clean inside the nest but she pecked inside sometimes after feeding while standing on the nest rim.

On 15 Aug., the young was weighed and handled for the first time. Oniki collected 8 larvae of Diptera flies (Philornis sp.): one large on the belly, one medium on the back and six small ones scattered on the body (see Table 1). The differences in size and Table 1 confirm repeated infestation 
observed by Oniki (1983) in other species. Later, other larvae were removed, for a total of 58. The total mass of larvae removed was over $6.9 \mathrm{gms}$, equal to the mass of a young bird 8-9 days old. When weighed with larvae, the young was heavier than after removal (Table 1).

The entrance wound of the larva was different from ones observed in Passeriformes: a dot in the center with the surrounding skin encircling it, looking like a "flower". Larvae considered large enough to pupate were removed with a forceps and placed in a jar with wet sand and covered with cloth (Oniki, 1983). Eclosion of pupae was 9-12 days after larvae were placed in the jar (4 cases). After removal of the larva, scars healed well but when the larva was large a small dot of dried blood could remain at the entrance hole, dropping in a few days.

The feces ejected by young, glued to surrounding leaves, attracted adult Diptera: 22 Aug., 16:30, one fly seen; also at 16:56, when it walked inside the nest rather than flee when Oniki tried to catch it; 24 Aug., 1 adult collected; 27 Aug., 11:22 and 15:10, 1 fly collected at each hour: 31 Aug., 10:34 (1 fly seen); 5 Sept., 10:57 (2 flies seen) and 12:41 (1 fly seen). Adult flies were not detected before 10:30 am.

\section{DISCUSSION}

Nesting of this open-area species includes the winter months, perhaps because the nest is somewhat exposed and heated by the sun. Midday and afternoon heat seemed to reduce brooding time and feeding by the female, but did bother the young as it got older - beak opening, preening and stretching wings, turning on the nest.

Lack of brooding after the first week or so, plus lack of brooding at night, is common in hummingbirds and may be necessary because of the small nest. When there are two young, there is little room for the female to brood. Even here, with one young, it occupied much of the nest interior after 10 days. It may be that young have to grow feathers rapidly to become endothermic early, due to small nests. These are probably necessary to avoid predation.

The extreme botfly parasitism here probably would have killed the young if Oniki had not collected the larvae.

Their total weight, at collection, was that of another young bird. These flies attack mostly at forest edges (Oniki, 1983), and may be especially dangerous at edges of towns. However, Eupetomena seems common in suburban zones, and sometimes fledges young. Possibly, flies are less common far from the forest edges about $1 \mathrm{~km}$ east of the present site.

Attacks on local birds were mostly of noncompetitors. Avoiding possible predator attraction is the most probable reason, notably in attacking ground-doves that started to roost in the nest tree.

Acknowledgments - We appreciate the help of students A. Z. Antunes, V. M. Borges, E. L. Gomes, R. Paiva Sobrinho, and C. C. C. Ruivo, learning how to study nests. G. A. Bencke showed us the nest. Oniki appreciates a fellowship from $\mathrm{CNPq}$ (Conselho Nacional de Pesquisa e Desenvolvimento Tecnólogico) while she was associate researcher at the Zoology Department (UNESP). Publication n. 13 of the Institute for Studies of Nature.

\section{REFERENCES}

ERICKSON, H. T. \& MUMFORD, R. E., 1976, Notes on birds of the Viçosa, Brazil region. Dept. Forest. and Nat. Resources. Agric. Exp. Sta., Purdue Univ., Bull., (131): $1-29$.

GRANTSAU, R., 1988, Os beija-flores do Brasil. Expressão e Cultura, Rio de Janeiro.

MEYER DE SCHAUENSEE, R., 1970, A guide to the birds of South America. Wynnewood, Pennsylvania, 470p.

ONIKI, Y., 1983, Notes on fly (Muscidae) parasitism of nestlings of South American birds. Gerfaut, 73: 281-286.

ONIKI, Y., 1996, Band sizes of south-eastern Brazilian hummingbirds. J. Field Ornithol., 67(3): 387-391.

RUSCHI, A., 1986, Aves do Brasil. Vols. 4 e 5. Expressão e Cultura, Rio de Janeiro, 482p.

SNETHLAGE, H., 1928, Meine Reise durch Nordostbrasilien. III. Bausteine zur Biologie der angetroffenen Arten. J. Ornithol., 76: 668-738. 